\title{
FINE STRUCTURAL AND IMMUNOHISTOCHEMICAL IDENTIFICATION OF GH, PROLACTIN, AND ACTH CELLS IN THE C57BL MALE MOUSE
}

\author{
TAKASHI YASHIRO
}

Department of Anatomy, St. Marianna University School of Medicine, Sugao, Miyamaeku, Kawasaki, Kanagawa 213, Japan

\begin{abstract}
An immunohistochemical study of the pituitary glands of C57BL male mice was conducted in order to reconsider the classical fine structural identification of $\mathrm{GH}$, prolactin, and ACTH cells. The fine structural properties of each cell type were examined on ultrathin sections adjacent to semithin Epon sections stained immunohistochemically. Immunoreactive GH cells showing little morphological variation roughly coincided with the classical GH cells. Prolactin cells were divided into three types on the basis of the morphology of the secretory granules: 1) cells containing only small spherical granules, which showed the highest incidence in the gland; 2) cells containing polymorphic or irregular granules which coincided with the classically identified prolactin cell granules; 3 ) cells containing both spherical and polymorphic granules. ACTH cells were divided into cells resembling Siperstein's 'corticotrophs' and uncommon type cells, which were heavily granulated and/ or contained large granules.
\end{abstract}

Electron microscopic studies of hormone producing cell types in the anterior pituitary gland have been performed for many years. Knowledge in this field has been derived mainly from studies using rat pituitary gland. Focusing on the simple protein hormone producing cells, Farquhar and Rinehart (4) and Rinehart and Farquhar (15) first identified GH cells by electron microscopy. Smith and Farquhar (21, 22) and Shiino et al. (18) identified prolactin cells with characteristic polymorphic secretory granules. Two different types of cells were distinguished as ACTH cells, one by Kurosumi and Kobayashi (5) and Rennels and Shiino (16), and the other by Siperstein $(19,20)$.

However, these classical identification criteria have been reconsidered by many researchers with the advent of immunohistochemistry. Nakane $(10,11)$ confirmed the morphological criteria of GH cells. ACTH cells, which were identified by Siperstein as cells characterized by rows of secretory granules beneath the cell membrane, were also identified by Moriarty and Halmi (8) and Moriarty et al. (9). In regard to prolactin cells, Nogami and Yoshimura $(13,14)$ reported that the polymorphic shape of the granules was not necessarily the criterion for identifying the cells in the male.

As for the mouse pituitary, the cell typing by Barnes $(1,2)$ is well known. By studying the pituitaries from animals in various functional states, she identified $\mathrm{GH}$, prolactin, TSH, LH, and FSH cells. Yamada and Yamashita (26) investigated glands from normal and adrenalectomized mice to study the possible site of ACTH production.

The classical criteria for the classification of rat pituitary cells have been immunohistochemically reconsidered by many researchers, and an agreement regarding the fine structural criteria seems to have been reached. However, there have been no attempts at reconsidering the 
classical criteria of the pituitary cells in the mouse. This study aims at reexamining those mouse cells identified as $\mathrm{GH}$, prolactin, and ACTH cells using immunohistochemistry.

\section{MATERIALS AND METHODS}

Eight 60-day-old male C57BL/6J mice (20-25 g/B.W., Japan Crea, Tokyo) were killed under nembutal anesthesia. The pituitaries were removed, cut into small pieces with a razor blade, fixed in a $1 \%$ glutar-aldehyde solution prepared with a $0.1 \mathrm{M}$ phosphate buffer, $\mathrm{pH} 7.4$, for $2 \mathrm{~h}$ at $4^{\circ} \mathrm{C}$, and washed with $0.1 \mathrm{M}$ phosphate buffer containing $2 \%$ sucrose. The tissue blocks were post-fixed in $1 \%$ osmium tetraoxide in Millonig's buffer (6) for $2.5 \mathrm{~h}$ at $4^{\circ} \mathrm{C}$. After dehydration in ascending concentrations of cold ethanol and treatment with propylenoxide, they were infiltrated and embedded in Epon-Alardite (7).

Adjacent plastic sections were cut at $50 \mathrm{~nm}$ and $2 \mu \mathrm{m}$ thicknesses for electron microscopy and immunostaining, respectively. The thin sections were stained with a saturated uranyl acetate solution (23), and then a lead citrate solution (17), to be viewed with a JEOL 100B type electron microscope. The thick sections had the plastic removed for immunohistochemical staining by treatment with $14 \%$ sodium methylate $\left(\mathrm{NaOCH}_{3}\right)$ in methanol for $10 \mathrm{~min}$, followed by immersion in $2 \%$ hydrogen peroxide $\left(\mathrm{H}_{2} \mathrm{O}_{2}\right)$ for $20 \mathrm{~min}$ at room temperature.

Immunostaining was conducted according to Nakane's labeled antibody method (12). Antirat GH monkey serum $(1: 100)$, antimouse prolactin rabbit serum $(1: 1,000)$, and antiporcine $\mathrm{ACTH}^{1-39}$ rabbit serum $(1: 1,000)$ were used for the first antisera. Peroxidase conjugated IgG fraction goat anti-monkey $\operatorname{IgG}(1: 50)$, and peroxidase conjugated IgG fraction goat anti-rabbit $\operatorname{IgG}(1: 50)$, both from Cappel laboratories, Cochranville, PA, were used as the second antibody. All were diluted with phosphate-buffered saline $(0.154 \mathrm{M} \mathrm{NaCl} / 0.02$ $\mathrm{M}$ phosphate buffer, $\mathrm{pH}$ 7.4). Coloration was performed in $\mathrm{DAB}$ solution $\left(0.004 \% 3,3^{\prime}\right.$ diaminobenzidine tetrahydrochloride, $0.003 \%$ $\mathrm{H}_{2} \mathrm{O}_{2} / 0.005 \mathrm{M}$ Tris- $\mathrm{HCl}$, pH 7.4).

Absorption tests were carried out on plastic sections and/or paraffin sections (sublimateformalin fixation) of normal mouse pituitary glands in order to examine the specificity of the antisera. The antisera were absorbed at $4^{\circ} \mathrm{C}$ for 2 days with 1 or $10 \mu \mathrm{g}$ of the following hormones: rat GH (NIAMDD rat GH I-4); rat prolactin (NIAMDD rat PRL I-5); and porcine $\mathrm{ACTH}^{1-39}$ (Sigma, grade II). Only rat GH, rat prolactin, and porcine ACTH abolished the stainability of rat $\mathrm{GH}$, mouse prolactin, and porcine ACTH antisera, respectively, at any of the doses tested. Other hormones did not affect their stainability.

About 100 immunoreactive GH and ACTH cells and about 50 prolactin cells, containing only spherical secretory granules in the cytoplasm, were randomly selected. The diameters of 10 to 20 secretory granules from one cell which showed clear membranes were measured on the photographs in order to construct histograms of the secretory granule size in each cell.

\section{RESULTS}

\section{GH Cells}

Light microscopic immunostaining using the anti-rat GH serum is shown in the inset of Fig. 1, which is the electron micrograph of the adjacent section showing the fine structure of the GH secreting cells (cells A, B, and C). The immunostainability to the antiserum was nearly uniform among all immunoreactive cells (Fig. 1 inset), and the ultrastractural variations among the cells were small when compared with those of prolactin and ACTH cells. The outlines of the GH cells were generally spherical or oval. Large numbers of dense secretory granules were scattered throughout the cytoplasm. The diameter of the granules ranged from 175 to 450 $\mathrm{nm}$ with an average of approximately $300 \mathrm{~nm}$. The histogram is shown in Fig. 7. The rough surface endoplasmic reticulum appeared as a series of flattened sacs in parallel rows and more frequently occupying the perinuclear space surrounding the nuclei than the peripheral regions of the cytoplasm. The Golgi apparatus were small and infrequent.

\section{Prolactin Cells}

Immunoreactive prolactin cells were generally polygonal or irregular in shape and often had elongated cytoplasmic processes surrounding neighboring cells as shown in Fig. 2a. Oval or spherical prolactin cells were rare. The morphology of the secretory granules enabled the prolactin cells to be divided into three types: 1 ) cells containing only small spherical granules, 2) cells containing polymorphic or irregularly shaped granules, and 3) cells containing both spherical and polymorphic granules. The first 


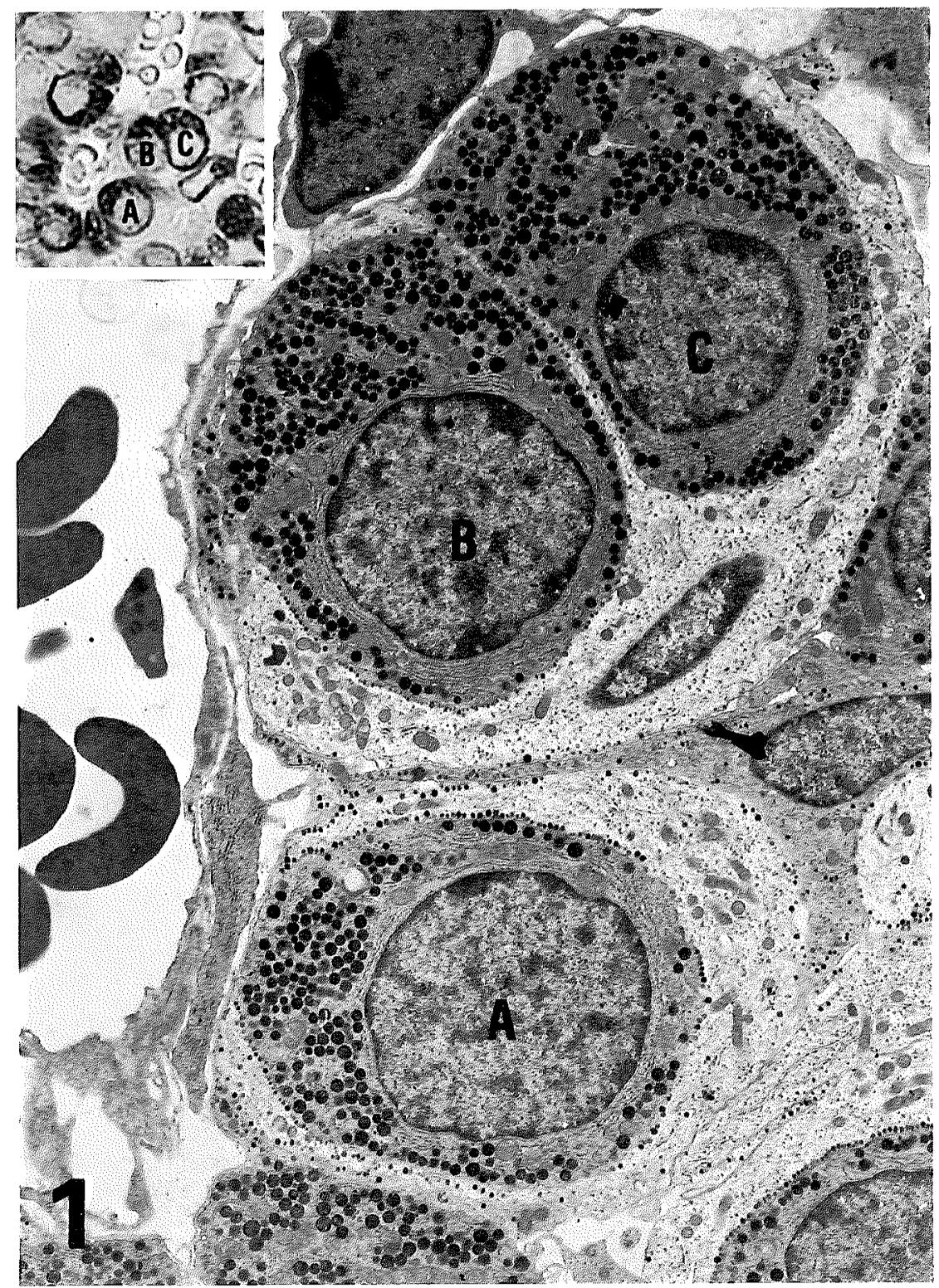

Fig. 1 Two adjacent light microscopic and electron microscopic sections. Cells A, B, and $\mathrm{C}$ correspond to the cells immunostained with anti-rat $\mathrm{GH}$ serum in the inset. There is almost no ultrastructural variation among the cells. $\times 5,500$

type (cells $D$ and $E$ in Fig. 2c) was the most commonly observed type of prolactin cells. These cells were characterized by small spherical secretory granules randomly distributed in the cytoplasm, ranging from 75 to $275 \mathrm{~nm}$ in diameter with an average of about $150 \mathrm{~nm}$ (Fig. 8). Their electron densities varied from low to high
(Fig. 2b). A high N/C ratio was also a characteristic of this type of cell. Their rough surface endoplasmic reticulum appeared flattened and small Golgi apparatus were sometimes encountered.

A second type of prolactin cells could sometimes be observed in the gland and had polymor- 


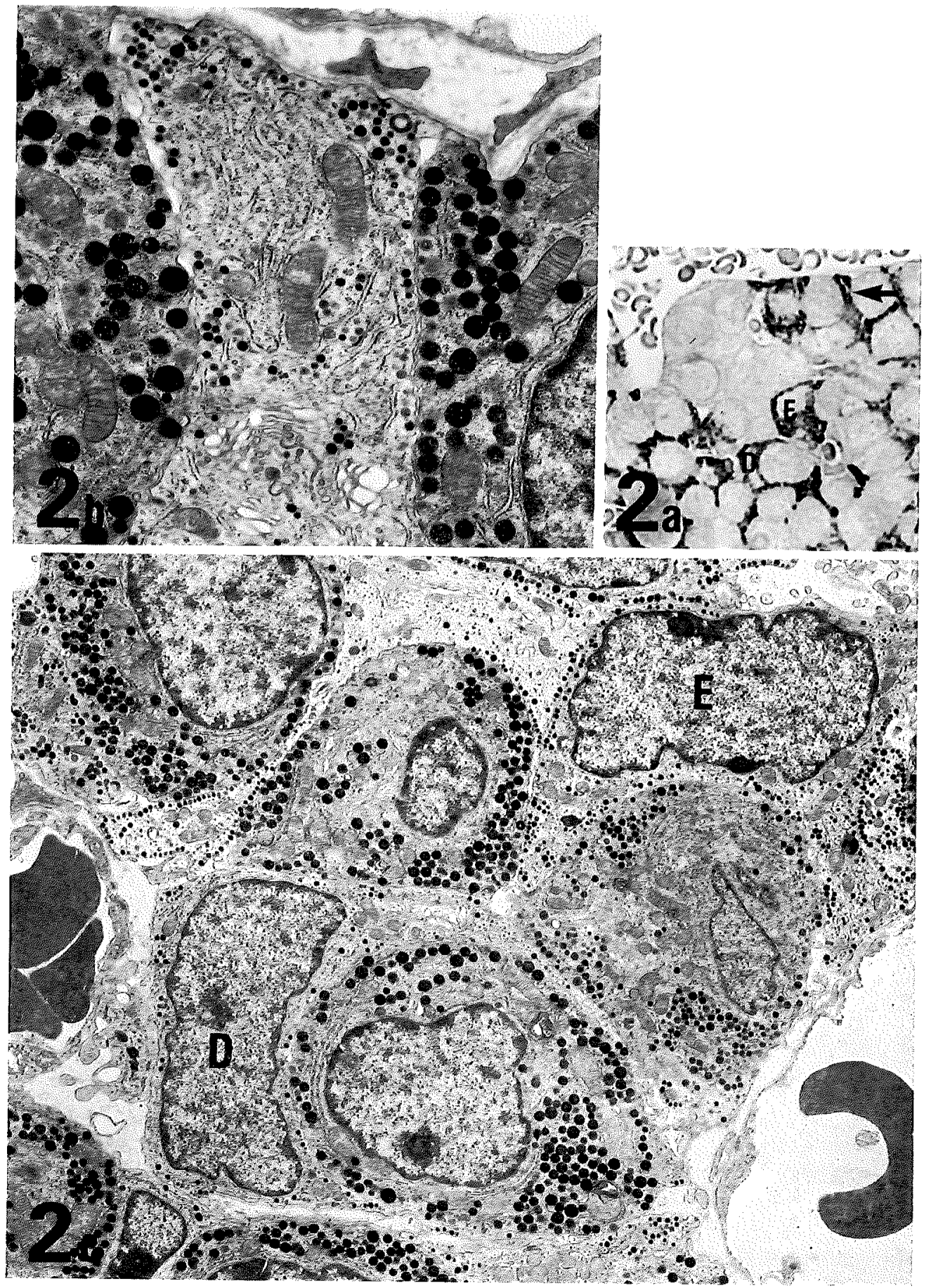

Fig. 2 
phic or irregularly shaped secretory granules. The maximum diameter of the granules measured about $300-400 \mathrm{~nm}$. The Golgi apparatus appeared more developed than in the first type of cells. In addition to the two types of prolactin cells, there were cells containing spherical and polymorphic granules but these were rare.

\section{ACTH Cells}

Immunoreactive ACTH cells were irregular or

Fig. 2 A section immunostained for light microscopy using anti-mouse prolactin serum (Fig. 2a) and the adjacent electron microscopic section (Figs. 2b and 2c). The highly magnified cytoplasm (Fig. 2b) corresponds to that of the immunoreactive cell marked by the arrow, and cells D and E (Fig. 2c) correspond to the immunoreactive cells in Fig. 2a. Small secretory granules, flattened rough surface endoplasmic reticulum, and small Golgi apparatus are observed. Compare the size of the mitochondria and granules with the size of those in $\mathrm{GH}$ cells. $\times 14,400(2 \mathrm{~b}), \times 5,300(2 \mathrm{c})$ stellate in shape, and often had elongated cytoplasmic processes enveloping neighboring cells. There were two groups of immunoreactive ACTH cells within the gland which had significantly different incidence rates. The most frequently observed cell type (cell F in Fig. 4) had weaker immunoreactivity than the other (Figs. 5a and 6a). The immunoreaction occurred along the cell membrane with no reaction in the central part of the cytoplasm. The findings suggest that this type of ACTH cell does not occur singly, but gathers into small clusters. Relatively small secretory granules ranging from 75 to $150 \mathrm{~nm}$ in diameter were arranged along the cell membrane. Rough surface endoplasmic reticulum appeared in parallel lines randomly distributed throughout the cytoplasm, and Golgi apparatus were not prominent.

The less frequent type of ACTH cells (Figs. $5 b, 6 b$, and $6 \mathrm{c}$ ) showed no difference in cell shape and the features of cell organella when compared with the common type ACTH cells, except for the number and the size of the secretory granules. The cell in Fig. 5b contains many small granules

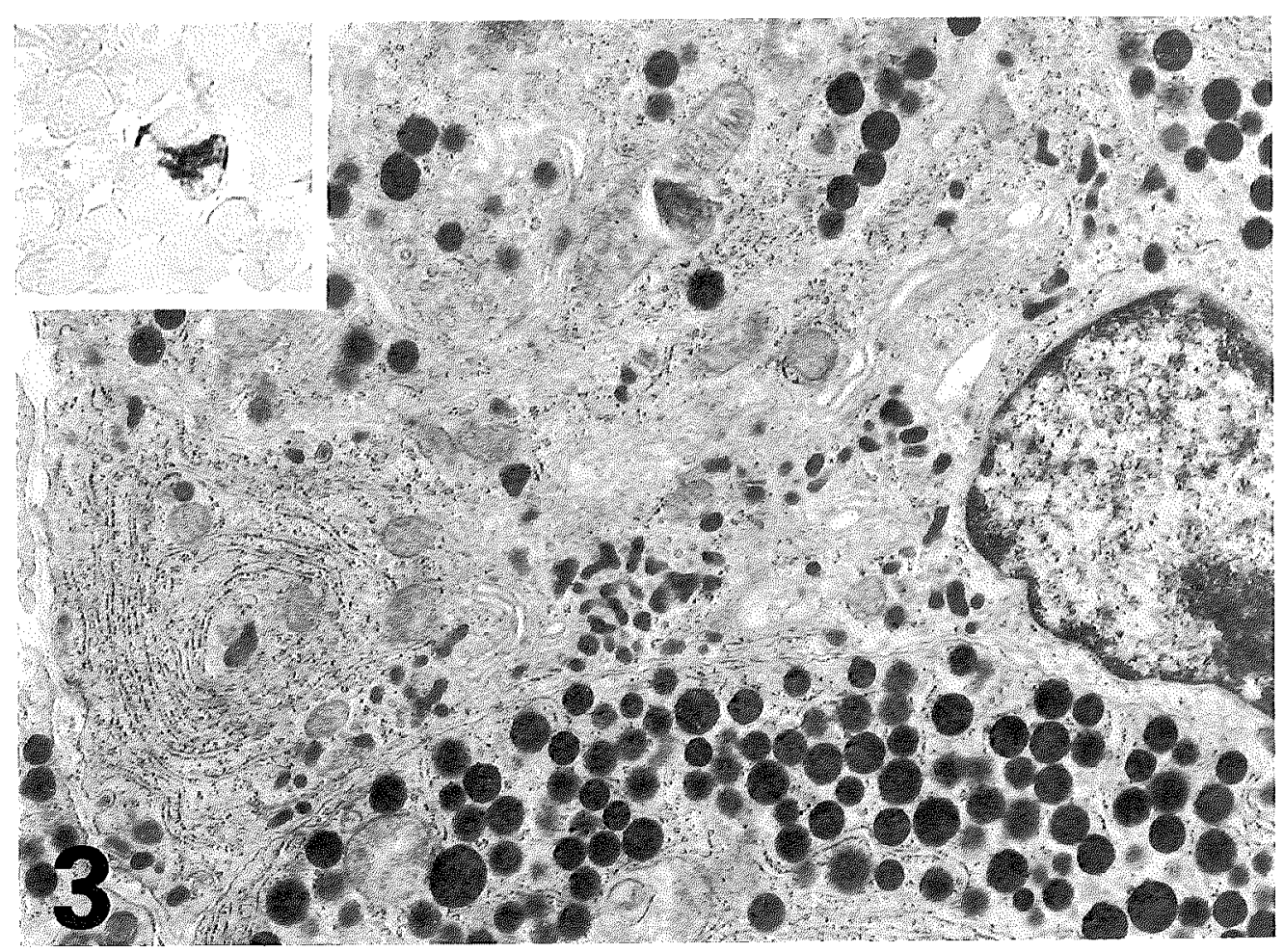

Fig. 3 Prolactin cell with polymorphic or irregular secretory granules (300 to $450 \mathrm{~nm}$ in maximum diameter). Relatively well developed Golgi apparatus and rough surface endoplasmic reticulumn are noted. $\times 13,200$ 


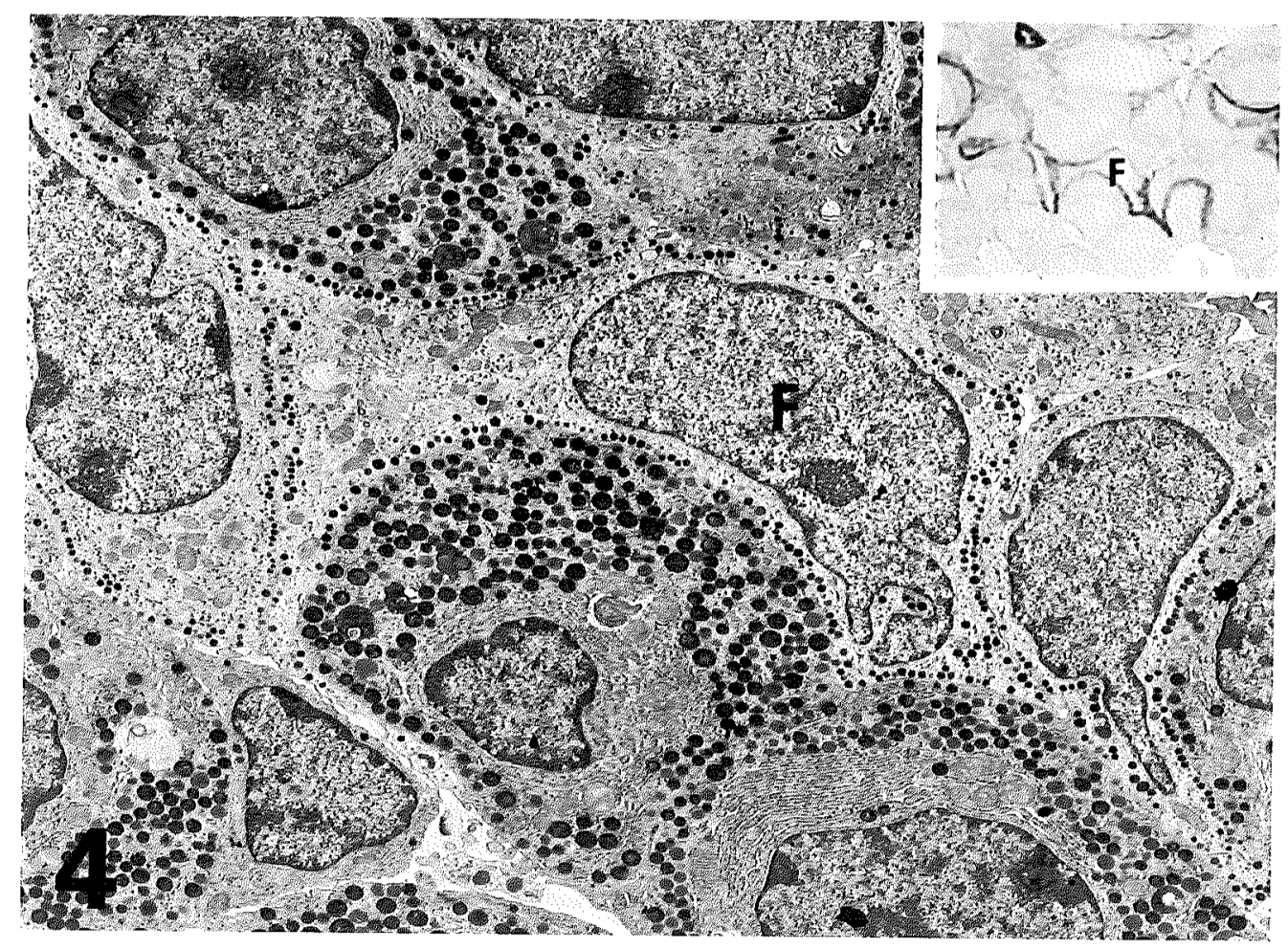

Fig. 4 A section immunostained for light microscopy using anti-porcine ACTH serum (inset) and the adjacent electron microscopic section. A few weakly immunoreactive cells are observed in the inset and their fine structure is similar to that of Siperstein's 'corticotrophs' in the rat. $\times 5,800$

(about 75 to $150 \mathrm{~nm}$ ) and cell $\mathrm{H}$ in Fig. 6 has larger sized granules (about 150 to $250 \mathrm{~nm}$ ). All areas of cytoplasm are strongly immunoreactive. Cell $G$ is characterized by the row of granules along the cell membrane, and is similar to the common type of ACTH cell. However, the granule size is larger. Incidence of these types of ACTH cells was low and they often existed singly.

Fig. 8 shows the histogram of the sizes of the secretory granules. Their diameters range from 75 to $250 \mathrm{~nm}$ with an average of about $130 \mathrm{~nm}$.

\section{DISCUSSION}

The fine structure of immunoreactive GH cells in the mouse is characterized by the following features: 1) spherical or oval cell shape; 2) large numbers of dense secretory granules scattered throughout the cytoplasm, ranging from 175 to $450 \mathrm{~nm}$ in diameter; and 3) a rough surface endoplasmic reticulum exhibiting developed parallel lamellae. These characteristics roughly coincide with those of 'the first type cell' of
Yamada and Sano (25) and of the commonly observed GH cells identified by Barnes $(1,2)$. Barnes distinguished a second type of hypertrophied GH cells, which were characterized by markedly enlarged endoplasmic reticulum, an irregular outline, enlarged Golgi apparatus, and large electron-lucent mitochondria. However, this type of $\mathrm{GH}$ cell was not distinguished in the present immunohistochemical study, and the ultrastructural variations among immunoreactive GH cells were so small that almost every GH cell had the characteristic features mentioned above. It seems easier to recognize the GH cells with these features than other

Fig. 5 Fig. 5b shows the immunoreactive cells corresponding to those marked by the arrow in Fig. 5a. Small secretory granules occupy most of the cytoplasm. $\times 5,600$

Fig. 6 Immunoreactive cells $\mathrm{G}$ and $\mathrm{H}$ in Fig. 6a correspond to the cells in Figs. $6 \mathrm{~b}$ and $6 \mathrm{c}$. Both cells contain large secretory granules. $\times 4,600(6 \mathrm{~b})$, $\times 6,200(6 \mathrm{c})$ 


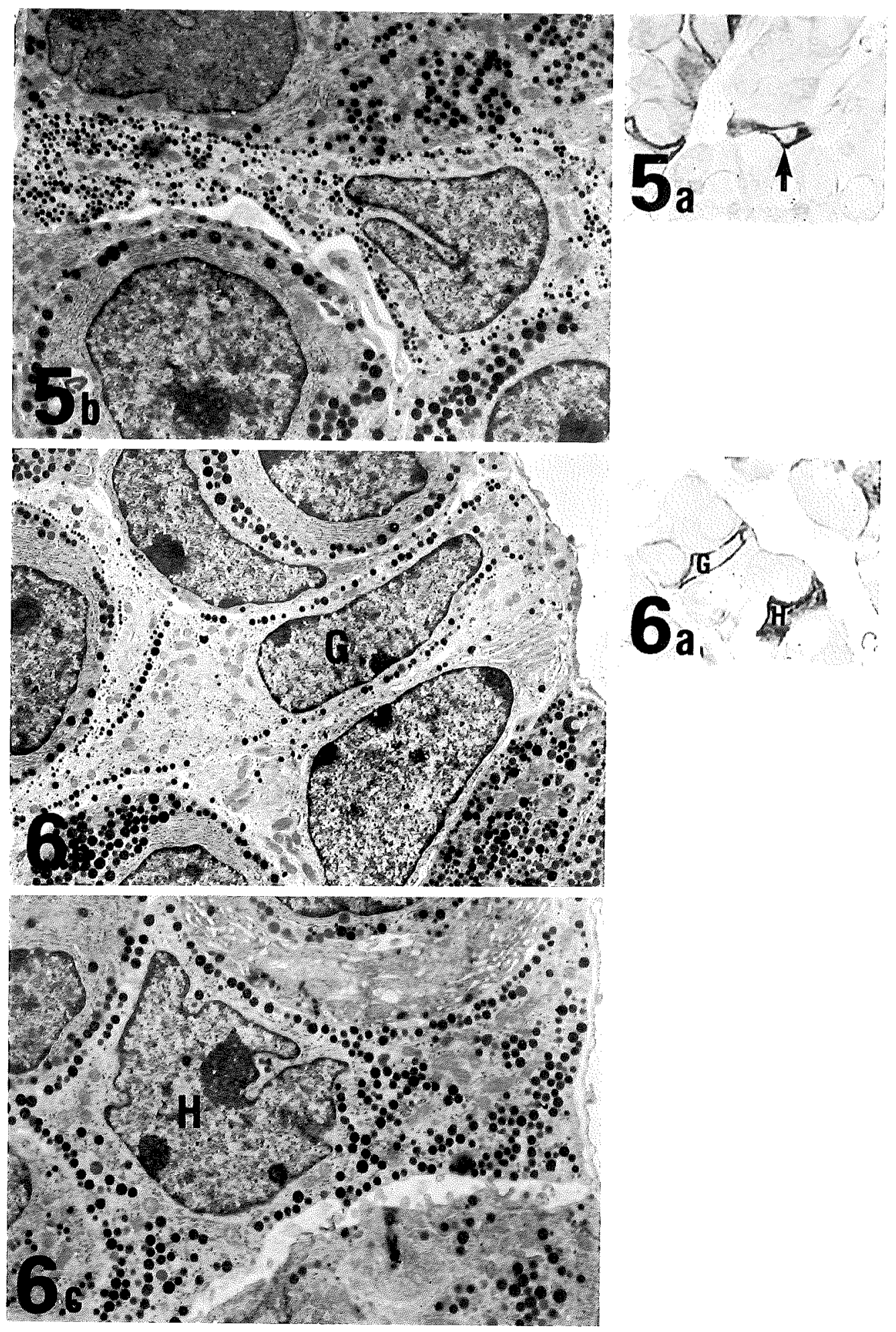

Figs. 5 and 6 

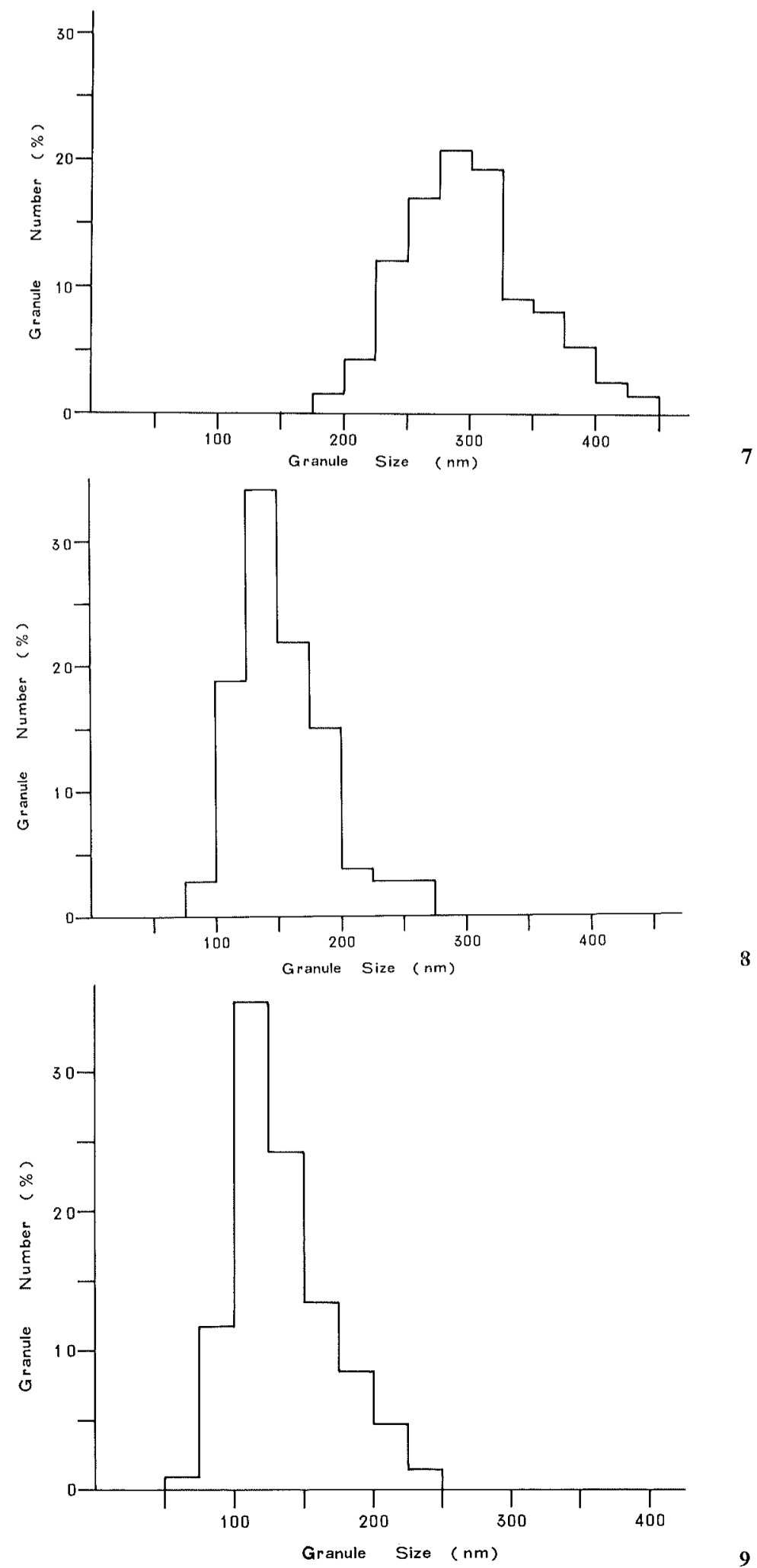

Figs. 7-9 
kinds of hormone producing cells in the gland, and the fine structure of $\mathrm{GH}$ cells in the mouse seems to be similar to that of GH cells in rats.

The histometrical study on the size of the secretory granules of the $\mathrm{GH}$ cells clearly showed that they average about $300 \mathrm{~nm}$ in diameter, ranging from 175 to $450 \mathrm{~nm}$. These values are smaller than those reported by Barnes (350 to $400 \mathrm{~nm}$, but occasionally as large as $500 \mathrm{~nm}$, using the TT, $\mathrm{C}^{+}$, or Charles River strains) (2), Wilson and Christensen (350 to $400 \mathrm{~nm}$ using the C57BL strain) (24), or Yamada and Yamashita (350 to $400 \mathrm{~nm}$ using the dd-N strain) (26). These differences may be due to inaccurate histometrical calculation or to the different strain of animals used.

A few interesting reports on the morphology of prolactin cells have recently appeared. Cells containing small spherical granules were shown to be prolactin cells immunohistochemically in female guinea pigs (3) and male rats $(13,14)$. Nogami and Yoshimura (14), especially, distinguished four prolactin cell types: 1) oval, polygonal, and elongate cells with only small spherical granules (130 to $200 \mathrm{~nm}$ ); 2) oval or polygonal cells with both medium-sized spherical granules ( 250 to $300 \mathrm{~nm})$ and about the same size of polymorphic granules; 3) polygonal cells containing only large polymorphic granules ( 300 to $700 \mathrm{~nm}$ in maximum diameter); and 4) cup-shaped cells. They concluded that the polymorphic shape of the granules is not necessarily an absolute criterion for identifying the prolactin cell in the male rat.

The prolactin cells of the mouse differ from those of the rat in the following respects: 1) oval prolactin cells are rare, 2) typical cupshaped cells enveloping gonadotrophs (10) do not occur, 3) polygonal granules are smaller (350 to $400 \mathrm{~nm}$ in maxmum diameter) and more irregular, and 4) the spherical granules (75 to $275 \mathrm{~nm}$ with an average of about $150 \mathrm{~nm}$ ) are relatively smaller than those of the rat. Though these differences were recognized, it should be noted that prolactin cells with only spherical granules exist both in rats and mice.

Polymorphic granules characterized the prolactin cells in the pituitary of not only the rat but also of the mouse $(1,2,24,26,27)$. Cells of

Figs. 7, 8, and 9 Histograms of the size of secretory granules of GH cells (Fig. 7), prolactin cells containing only spherical granules (Fig. 8), and ACTH cells (Fig. 9). Distribution of granules is expressed as the proportion of total granules. this type actually gained prolactin immunoreactivity in this study (Fig. 3). However, the incidence of this type cell is low in the male gland, as mentioned by Barnes (1), and cells with small spherical granules make up the majority of prolactin cells. It is unclear what type of classical cell coincides with this new type cell, and its relation to other type cells is unknown.

Yamada and Yamashita (26) observed ACTH cells in the pituitaries from normal and adrenalectomized mice. According to them, the Golgi apparatus occupies a major part of the cytoplasm, and the immature form of the granules with high electron density around the Golgi area becomes vesiculated in the cell periphery with osmium fixation. However, the typical immunoreactive ACTH cells elucidated in this study showed irregular or stellate cell shapes, arrangement of granules in a row along the cell membrane, and insignificant Golgi apparatus. These features are in common with those of the ACTH cells identified by Siperstein in the rat $(19,20)$. The ACTH cells identified by Yamada and Yamashita (26) seem to differ from the cells immunohistochemically identified in this study.

In addition to cells like Siperstein's 'corticotroph', ACTH cells heavily granulated and/or containing larger granules (Figs. 5 and 6) were distinguished, although rarely. Typical and commonly observed ACTH cells, exhibiting Siperstein's 'corticotroph'-like features, have a tendency to form clusters, whereas other uncommon types of cells often occur singly. A similar cluster formation is observed in the postnatal development of thyrotrophs (28), which show immature fine structural properties. According to that report, thyrotrophs develop from clusters which subsequently break down and become scattered. These may later develop into mature granule-rich cells. The ACTH cells in Figs. 5 and 6 are heavily granulated and/or contain large granules and also exist singly within the gland. Therefore, the cells in Figs. 5 and 6 may be more mature than the commonly observed type of ACTH cell ( $\mathrm{F}$ type cells).

I am grateful to Dr A. F. Parlow, NIH, Bethesda, U.S.A., for kindly supplying rat $\mathrm{GH}$ antiserum, Dr K. Komoto, Tokyo University, for mouse prolactin antiserum, and Dr Y. G. Watanabe, Sapporo Medical College, for porcine ACTH antiserum. I also thank Dr J. P. Barron, St. Marianna University, for the revision of the manuscript and Dr T. Suzuki, St. Marianna University, for his encouragement throughout the experiment. 
Received for publication 17 March 1983; and in revised form 22 April 1983

\section{REFERENCES}

1. Barnes B. G. (1962) Electron microscope studies on the secretory cytology of the mouse anterior pituitary. Endocrinology 71, 618-628

2. BARnes B. G. (1963) Fine structure of the mouse adenohypophysis in various physiological states. In Cytologie de l'adnenohypophyse, Centre National de la Recherche Scientifique, Paris, pp. 91109

3. Beauvillain J. C., Mazzuca M. and Dubois M. P. (1977) The prolactin and growth-hormone producing cells of the guinea-pig pituitary. Electron microscopic study using immunocytochemical means. Cell Tissue Res, 184, 343-358

4. Farquhar M. G. and Rinehart J. F. (1954) Electron microscopic studies of the anterior pituitary gland of castrate rats. Endocrinology 54, 516-541

5. Kurosumi K. and Kobayashi Y. (1966) Corticotrophs in the anterior pituitary glands of normal and adrenalectomized rats as revealed by electron microscopy. Endocrinology 78, 745758

6. Millonig G. (1962) Further observations on a phosphate buffer for osmium solutions in fixation. In Electron Microscopy, Fifth International Congress for Electron Microscopy 2, Academic Press, New York, p. 8

7. Mollenhauer H. H. (1964) Plastic embedding mixtures for use in electron microscopy. Stain Technol. 39, 111-114

8. Moriarty G. C. and Halmi N. S. (1972) Electron microscopic study of the adrenocorticotropin-producing cell with the use of unlabeled antibody and the soluble peroxidase-antiperoxidase complex. J. Histochem. Cytochem. 20, 590-603

9. Moriarty G. C., Halmi N.S. and Moriarty C. M. (1979) The effect of stress on the cytology and immunocytochemistry of pars intermedia cells in the rat pituitary. Endocrinology 96, 1426-1436

10. NaKane P. K. (1970) Classifications of anterior pituitary cell types with immunoenzyme histochemistry. J. Histochem. Cytochem. 18, 9-20

11. NAKANe P. K. (1971) Application of peroxidaselabelled antibodies to the intracellular localization of hormones. Acta Endocrinol., Suppl. 153, 190-204

12. Nakane P. K. and Pierce G. B. (1966) Enzymelabeled antibodies: Preparation and application for the localization of antigens. J. Histochem. Cytochem. 14, 929-931

13. Nogami H. and Yoshimura F. (1980) Prolactin immunoreactivity of acidophils of the small granule type. Cell Tissue Res. 211, 1-4
14. Nogami H. and Yoshimura F. (1982) Fine structural criteria of prolactin cells identified immunohistochemically in the male rat. Anat. Rec. 202, 261-274

15. Rinehart J. F. and Farquhar M. G. (1953) Electron microscope studies of the anterior pituitary gland. J. Histochem. Cytochem. 1, 93-113

16. Rennels E. G. and Shino M. (1968) Ultrastructural manifestations of pituitary release of $\mathrm{ACTH}$ in the rat. Arch. Anat. Histol. Embryol. 51, $573-590$

17. Reynolds E. S. (1963) The use of lead citrate at high $\mathrm{pH}$ as an electron-opaque stain in electron microscopy. J. Cell Biol. 17, 208-212

18. Shitno M., Williams G. and Rennels E. G. (1972) Ultrastructural observation of pituitary release of prolactin in the rat by suckling stimulus. Endocrinology 90, 176-187

19. Siperstein E. R. and Allison V. F. (1969) Fine structure of the cells responsible for secretion of adrenocorticotrophin in the adrenalectomized rat. Endocrinology 76, 70-79

20. Siperstein E. R. and Miller K. J. (1970) Further cytophysiologic evidence for the identity of the cells that produce adrenocorticotrophic hormone. Endocrinology 86, 451-486

21. Smith R. E. and Farquhar M. G. (1966) Lysosome function in the regulation of the secretory process in cells of the anterior pituitary gland. J. Cell Biol. 31, 319-347

22. Smith R. E. and Farquhar M. G. (1970) Modulation in nucleoside diphosphatase activity of mammotrophic cells of the rat adenohypophysis during secretion. J. Histochem. Cytochem. $18,237-250$

23. WATSON M. L. (1958) Staining of tissue sections for electron microscopy with heavy metals. $I$. Biophys. Biochem. Cytol. 4, 475-478

24. WiLson D. B. and Christensen E. (1980) Postnatal development of somatotrophs and mammotrophs in the pars distalis of the C57BL mouse. Cell Tissue Res. 211, 441-448

25. Yamada K. and Sano M. (1960) Electron microscopic observations of the anterior pituitary of the mouse. Okajimas Folia Anat. Jap. 34, 449. 475

26. Yamada K. and Yamashita K. (1967) An electron microscopic study on the possible site of production of ACTH in the anterior pituitary of mice. Z. Zellforsch. 80, 29-43

27. Yamashita K. (1969) Electron microscopic observations on the postnatal development of the anterior pituitary of the mouse. Gumma Symp. Endocrinol. 6, 177-196

28. Yashiro T., Nogami H. and Yoshimura F. (1981) Immunohistochemical study of the postnatal development of pituitary thyrotrophs in the rat, with special reference to cluster formation. Cell Tissue Res. 216, 39-46 